\title{
Ozone as integrative and complementary support for pharmacological therapy
}

\section{Lamberto $\mathrm{Re}$}

CLINICA MEDINAT, Ancona, Italy

\section{ว OPEN ACCESS}

\section{Citation}

$\operatorname{Re} \mathrm{L}$, Ozone as integrative and complementary support for pharmacological therapy. $J$ Ozone Ther. 2020:4(5)

doi: 10.7203/jo3t.4.5.2020.20770

\section{Academic Editor \\ Jose Baeza-Noci, \\ School of Medicine, Valencia \\ University, SPAIN}

\section{Editor}

World Federation of Ozone Therapy,

Brescia, ITALY

\section{Received}

April 20, 2019

\section{Accepted}

July 20, 2019

\section{Published}

December 15, 2020

\section{Intellectual Property}

Re L.

This is an open access article distributed under the terms of the Creative Commons Attribution License (CC BY 4.0), which permits unrestricted use, distribution, and reproduction in any medium, provided the original author and source are credited.

\section{Authors information \\ info@lambertore.com}

\section{ABSTRACT}

Ozone is not nowadays used as a single medical branch, due to its immune and metabolic effects. This molecule is considered as a pro-drug which by inducing certain non-toxic doses a rearrangement of the biochemical pathways with the activation of a second messenger in a cascade with a multiple system action can be achieved. Nonetheless, its difference from a drug consists in the fact that its action can't be explained as a simple interaction between a molecule and a receptor, thus, it can't be considered according to the classical pharmacological schemes and new concepts must be defined. Furthermore, ozone is able to activate Nfr2 protein. Our study reflects how the levels of Nrf2 in peripheral blood mononuclear cells were found to increase immediately after ozone. This metabolic pathway is common to all cell lines. In light of the above, ozone could be very helpful as integrative and complementary support for pharmacological therapy modulating the oxidative stress component in many illnesses, elderly and rare diseases, according to not only a legal regulation but also a proper education and training of physicians.

Key words: Oxidative Therapies; Ozone; Nrf2; Aging; Systems Medicine.

In recent years emphasis and attention have been focused on the use of medical ozone. Despite ample clarification (1) confusion still persists concerning its potential toxicity as strong oxidant.

This confusion is a major factor preventing a more widespread acceptance, despite its use in the medical field as a safety remedy has been reported since the XIX century (2).

Furthermore the use in specialties so different like neurology, orthopedics, internal medicine, sports medicine, endocrinology and others makes difficult the placement of ozone as a single specialist branch. This fact may cause conflict between the different fields of application and the various medical areas.

Ozone is widely described as one of the best treatment for disc intra-vertebral pathologies (3). Regarding this application, we again remember that the ozone effects are mainly due to its peculiar mechanism on the bio-humoral environment. Behind this effect, in recent years attention has been focused on the use of medical ozone and on its rationale in pain management $(4 ; 5 ; 6)$. Furthermore, it has been reported its action as an immune modulator and activator of cellular metabolism which shows long-term anti-inflammatory effects and reduces inflammation with an apparent low toxicity (7).

Ozone therapy increases the endogenous antioxidant system activities in endotoxic and septic shock models (8). However, so far there is only one study aimed at 
identifying the possible molecular mechanisms of the anti-allodynic/analgesic effect of ozone and the possible involvement of some inflammatory and apoptotic pathways (9).

Moreover, evidence that antioxidant enzymes, nitric oxide pathways and other subcellular activities could be modulated by low ozone doses is now proven and could support the surprising effects of ozone in many pathological conditions $(10 ; 11 ; 12)$.

Regarding the pharmacological characterization of the ozone molecule, at the light of the more recent knowledge we can consider ozone as a pro-drug which, at certain non-toxic doses, can induce a rearrangement of the biochemical pathways with the activation of a second messenger in a cascade with a multiple system action. Ischemic preconditioning represents the best similarity in this context. Noteworthy, the report of Wentworth et al. (13). Indeed, their scientific data demonstrates the physiological presence of an ozone-similar mediator during inflammation, indicating ozone as a new bio-molecule with striking effects which must be considered and studied following new strategies with newly constructed randomized-standardized clinical studies.

In addition, a large number of inflammatory and signaling substances, such as tumor necrosis factor and interleukins (interleukin-1beta, interleukin-6, and interleukin-8) $(14 ; 15)$ could be involved explaining the ozone action.

Looking at the more recent scientific discoveries, we introduced a new terminology regarding the pharmacological mechanism of action characterizing the treatment with ozone. Indeed, being quite different from a drug, its action can't be explained as a simple interaction between the molecule (drug) and the receptor (cellular membrane protein) - according to classical schemes of pharmacology currently spread in the faculties of medicine - but rather as "Hormetic Stress", firstly proposed by us in 2008 (16).

Our scientific conviction that a molecule like ozone, i.e. a strong oxidant, could induce benefits in various ailments, when used at low doses was believed to be an unconventional theory. We are now very happy to note how this concept could finally gain a certain scientific credibility.

In March 2014, Dr. James Watson, who co-discovered the double helix structure of DNA, proposed an unconventional view on the cause of diabetes. (17). "The fundamental cause, I suggest, is a lack of biological oxidants, not an excess," he says. "Physical exercise prompts the body to make large numbers of oxidants molecules called reactive oxygen species, or ROS," he continues, and that's why exercise is beneficial to our bodies. This hypothesis certainly needs to be tested. It could be that it's the balance that matters, and that disease results due to an imbalance on either side; i.e. both oxidative stress or oxidative deficiency (such as hypoxia), could lead to insulin resistance and other diseases. The idea that similar to a brief exercise, the conditioning effects induced by small ozone doses, could be helpful for many of the biological functions of all the cells that burn oxygen to produce energy seems to be worthy of new and strong scientific studies dedicated to the matter.

Anyway, one of the issues raised by the scientific community is: how ozone really acts on Humans? As already stated, ozone is quite different from a drug and its action is not a consequence of a binding reaction between one molecule (drug) 
and one receptor (cellular membrane protein). The fact makes more difficult the efforts of scientists in the evaluation of the molecular events underlying its clinical activity. For the above reasons the ozone action can't be considered according to classical schemes of pharmacology according to Michaelis-Menten Equation and new concepts must be defined according to the System Medicine concept.

To our opinion, reactions induced by stress mechanisms require the introduction of a third parameter in addition to the DOSE and the EFFECT: i.e. the TIME. In fact, differently from what happens for a conventional drug that acts on a specific target with an immediate action, stressing agents promote several biological effects through a myriad of interactions that involve many cellular processes and metabolic pathways which in turn produce a stable clinical effect only after a certain time.

Like other Xenobiotics, agents not recognized in the metabolism of the body (from the Greek Xenos = Foreign and Bios = Life), such as heat, mechanical trauma, ionizing radiation or the same foods that we eat daily, even "ozone" molecule is able to influence the cellular functions. Indeed, following the stress, cells promote protection mechanisms that defend from the specific damage induced by the same stressing agent. The term xenobiotic has been introduced only recently (18), and the details are still lacking of adequate scientific support regarding the involved mechanisms. As is obvious, this is reflected negatively in regards to ozone therapy too, and makes understandable, but not reasonable, the lack of attention of Health Authorities devoted to the control of human health.

So the studies to date are mostly directed to the characterization of the Mode of Action of the Stress Response (MOA), understood as the definition of individual metabolic pathways activated at the cellular level by the various Xenobiotics. Ozone, like other agents, and unlike the common drugs that act on a specific receptor, induces small stress to the whole cell when used at low doses. This, in turn, triggers a series of intracellular metabolic processes and promotes a myriad of intracellular activities. As a consequence of these reactions, the defense mechanisms of the cell are alarmed and enhanced to improve functionality, explaining in part the surprising therapeutic actions of this gas. A recent study published in the prestigious Toxicological Sciences (19) has fully explained the biochemical mechanism with its intracellular mediators (Transducers, Sensors and Transfer Factor), where for each type of xenobiotic is possible to monitor the intracellular metabolic pathways (Table 1).

Table 1. Intracellular metabolic pathways for each type of xenobiotic.

\begin{tabular}{|c|c|c|c|}
\hline Pathway & TF & Sensor & Major transducers \\
\hline Oxidative stress & $\mathrm{Nrf2}$ & Keap1 & MAPK, ERK, p38, PKC \\
\hline Heat shock response & HSF-1 & Hsp90 & $\mathrm{CaMK} 2, \mathrm{CK} 2$ \\
\hline DNA damage & p53 & MDM2 & ATM, JNK, Chk1, Chk2 \\
\hline Hypoxia & HIF-1 & VHL & $\mathrm{p} 38, \mathrm{PI} 3 \mathrm{~K}$ \\
\hline ER stress & XBP-1, ATF6, ATF4 & $\mathrm{BiP}$ & IRE $1 \alpha$, S2P \\
\hline Metal stress & MTF-1 & None & PKC, CKII, TKs \\
\hline Inflammation & $N F-\kappa B$ & IkB & IKK \\
\hline Osmotic stress & NFAT5 & None & p38, ATM, PKA \\
\hline
\end{tabular}


There is no doubt that this complexity makes us understand why it is not easy set up clinical trials demonstrating definitively the therapeutic power of these agents. On the other hand, any drug interaction, due to its direct bind with a receptor and consequent biological function activated, is easily measurable and statistically standardized. In short, the stimulus of Oxidative Stress, in the case of ozone, is able to activate Nrf2 protein (20) which, moving in the nucleus, starts production from part of Target Genes of proteins that promote cell functions (Figure 1), strengthening the defenses, and optimizing the underlying specific function.

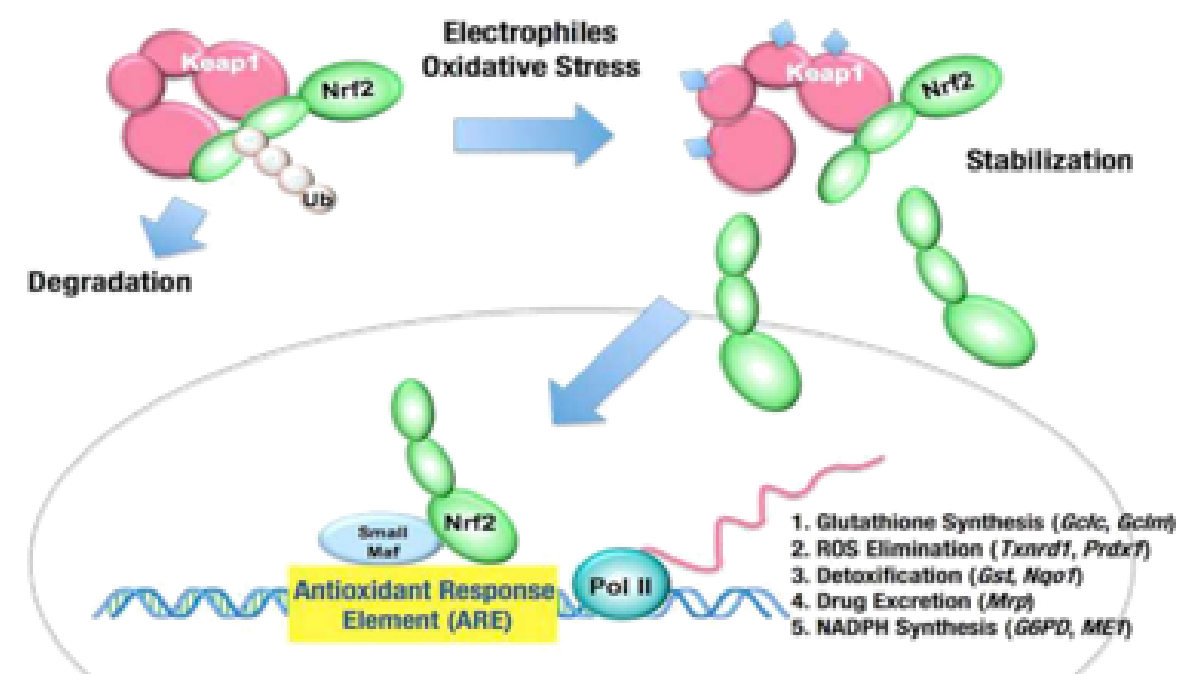

Figure 1. Ozone is able to activate the Nrf2 pathway which in sequence promotes the upregulation of Target Genes regulating the synthesis of proteins with specific functions.

In our study executed systemic indirect endovenous ozone therapy applications (SIEVOT) on healthy volunteers and we demonstrated the involvement of Nrf2 protein in vivo. Indeed, the levels of Nrf2 in peripheral blood mononuclear cells $(\mathrm{PMBC})$ were found to increase immediately after ozone exposure $(\mathrm{P}<0.01)$. This effect was still detected $(\mathrm{P}<0.05)$ in total circulating PBMC when measured $30 \mathrm{~min}$ following reinfusion demonstrating that the oxidative stress was able to activate all the blood components. After a series of 3 SIEVOT, Nrf2 returned back to the basal level. At the end of the experiment the activities of superoxide dismutase and catalase were increased $(\mathrm{P}<0.05)$. These data demonstrate for the first time in vivo the activation of the Nrf2 pathway by a low dose of ozone followed by the promotion of the feedback mechanism that induces the synthesis of proteins which collectively favors cell survival (21). 
We can now better understand why we usually observe so different beneficial effects after ozone therapy. Indeed, this metabolic pathway is common to all the cell lines. So, we will see an aesthetic effect if the conditioned cell is part of the skin tissue or a modulation action on inflammation if the cell is part of neuromuscular or bone tissues (Fig. 2).

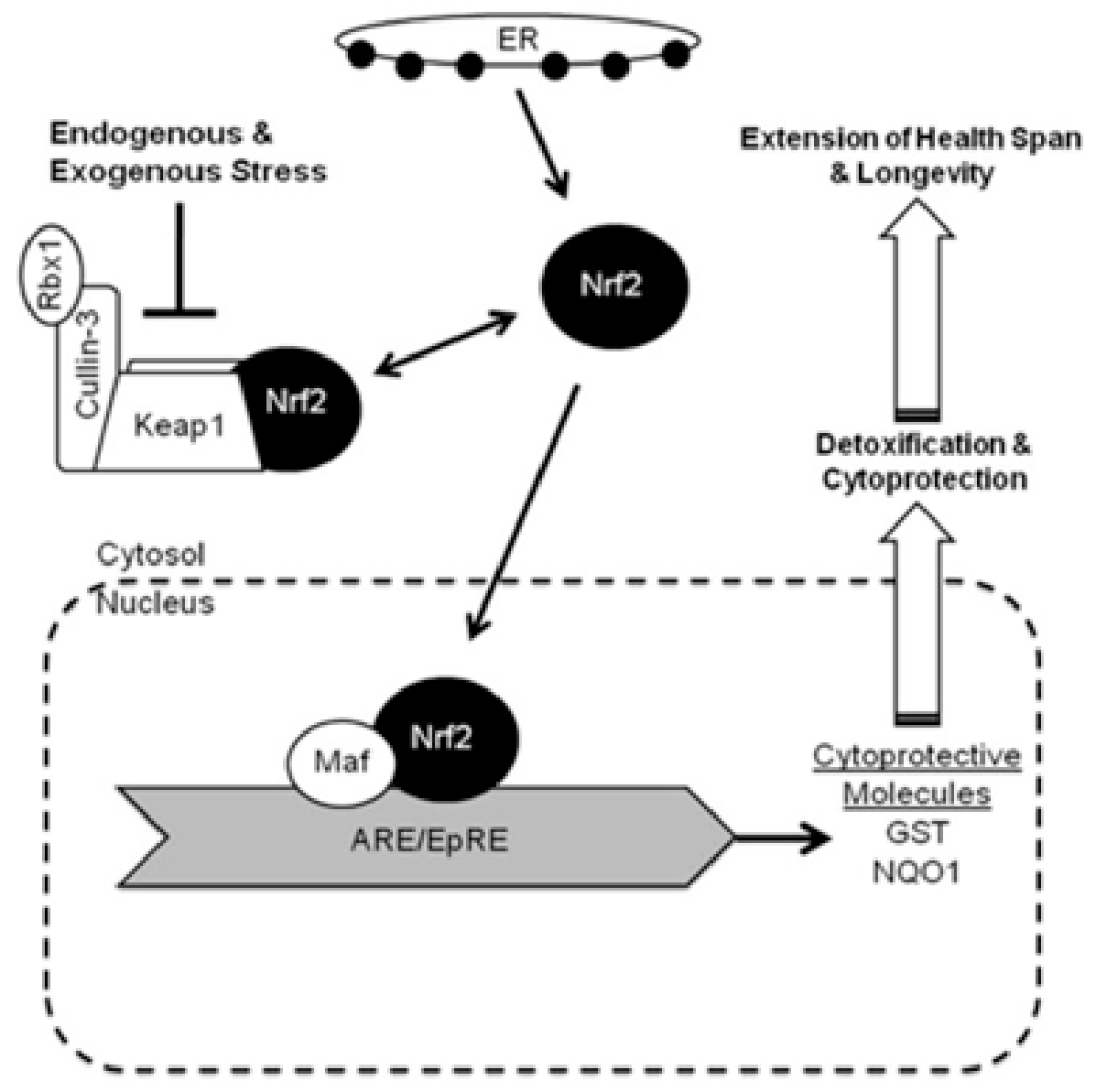

Figure 2. Upregulation of the genes in the ARE segment modulates several functions other than the oxidative pathway explaining the various effects induced by the mild oxidative stress promoted by ozone like those in the aesthetic, immune, inflammation and bone tissues fields.

Taking into account these last papers, we can conclude that ozone could be very helpful as integrative and complementary support for pharmacological therapy modulating the oxidative stress component in many illnesses.

Furthermore it could be emphasized its use in the elderly, where side effects and therapeutic costs are going to be even often a serious problem for the Health Authorities and for the medical care personnel (22).

Considering all the above, we can propose ozone therapy as a useful resource to complement and integrate the pharmacological approach actually utilized both for the most common symptoms and for rare diseases, still orphan of proper medical treatment (23). 
We believe that it is time for the scientific community to launch a serious assessment of ozone therapy that can rightfully be considered a strategic allied of the orthodox medicine, especially in the case of rare diseases still orphan of adequate drug treatment. A key factor of no small importance is also represented by the absence of important side effects, the incidence of which, considering the millions of patients submitted to this therapy all around the world over the last 40 years, it is represented by a number after the decimal point preceded by at least 5 zeros !!!

Moreover, in the aim to defense this medical therapy that can play a primary role in the prevention and treatment of the elderly population, a careful assessment of a legal regulation could no further be delayed. Indeed, the proper education and training of the medical and paramedical staff who will administer the therapy according to the most recent clinical indications approved by the scientific societies must be fairly ruled by the Health Authorities worldwide.

Ozone therapy, like other similar holistic approaches, could be included in the newly branch of Human Enhancement. This is one of the reasons that prompted some experts to establish a non-profit medical society for "scientific research, bioethical analysis and the enhancement of human health". Due to the increasingly long-lived population, the aim will be also to broaden the knowledge in the field of integrated and natural therapies in the aim of preventing aging and most of the pain pathologies of the elderly. 
Figure and table 1 key:

\begin{tabular}{|c|c|}
\hline TF & Transcription Factor \\
\hline Nrf2 & Nuclear Factor erythroid 2-Related Factor 2 \\
\hline Keap1 & Kelch-like ECH-Associated Protein 1 \\
\hline MAPK & Mitogen-Activated Protein Kinase \\
\hline ERK & Extracellular signal-Regulated Kinases \\
\hline P38 & MAPK signal pathway \\
\hline PKC & Protein Kinase C \\
\hline HSF-1 & Heat Shock Factor 1 \\
\hline Hsp90 & Heat Shock Protein 90 \\
\hline CaMK2 & Calmodulin-dependent Protein Kinase II \\
\hline CK2 / CK II & Casein Kinase 2 \\
\hline P53 & Protein 53 \\
\hline MDM2 & Murine Doble Minute 2 \\
\hline ATM & Serine/Threonine Kinase \\
\hline JNK & c-Jun N-terminal Kinase \\
\hline Chk1 & Checkpoint kinase 1 \\
\hline Chk2 & Checkpoint kinase 2 \\
\hline HIF-1 & Hypoxia-Inducible Factor 1 \\
\hline VHL & Von Hippel-Lindau tumor suppressor gene \\
\hline PI3K & Phosphoinositide 3-Kinases \\
\hline S2P & Membrane protein \\
\hline XBP-1 & X-box Binding Protein 1 \\
\hline ATF6 & Activating Transcription Factor 6 \\
\hline ATF4 & Activating Transcription Factor 4 \\
\hline BiP & Bi-Phosphate \\
\hline IRE1alfa & Inositol-Requiring Enzyme 1 alpha \\
\hline NF-kB & Nuclear Factor Kappa B \\
\hline MTF-1 & Metal-responsive Transcription Factor-1 \\
\hline IkB & $\begin{array}{l}\text { Nuclear factor of kappa light polypeptide gene enhancer in } \\
\text { B-cells inhibitor }\end{array}$ \\
\hline IKK & Inhibitor of nuclear factor-кB (ІкB) Kinase \\
\hline TKs & Tyrosine Kinase substrate \\
\hline NFAT5 & Nuclear Factor of Activated T-cells 5 \\
\hline PKA & Protein Kinase A \\
\hline $\mathrm{Ub}$ & Ubiquitination Process \\
\hline Maf & (small) \\
\hline Pol II & RNA Polymerase II \\
\hline Gclc & Glutamate-Cysteine Ligase Catalytic subunit \\
\hline Gclm & Glutamate-Cysteine Ligase Regulatory subunit \\
\hline Txnrd1 & Thioredoxin Reductase 1 \\
\hline Prdx1 & Peroxiredoxin 1 \\
\hline Gst & Glutathione S-Transferase \\
\hline Nq01 & NAD(P)H dehydrogenase [quinone] 1 \\
\hline Mrp & Multidrug Resistance-associated Protein \\
\hline G6PD & Glucose-6-Phosphate Dehydrogenase \\
\hline ME1 & Malic Enzyme 1 \\
\hline ARE & Antioxidant Response Element \\
\hline ROS & Reactive Oxygen Species \\
\hline NADPH & Nicotinamide Adenine Dinucleotide Phosphate Hydrogen \\
\hline ER & Endoplasmic Reticulum \\
\hline
\end{tabular}


Figure 2 key:

\begin{tabular}{l|l}
\hline ER & Endoplasmic Reticulum \\
\hline Nrf2 & Nuclear Factor erythroid 2-Related Factor 2 \\
\hline Keap1 & Kelch-like ECH-Associated Protein 1 \\
\hline Cullin-3 & $\begin{array}{l}\text { Component of Cullin-RING E3 ubiquitin ligases complexes } \\
\text { (CRLs) }\end{array}$ \\
\hline $\mathbf{R b x 1}$ & RING-box protein 1 \\
\hline Maf & Musculoaponeurotic fibrosarcmoa transcription factor \\
\hline ARE & Antioxidant Response Element \\
\hline EpRE & Electrophile Responsive Element \\
\hline GST & Glutathione S-Transferase \\
\hline NQ01 & NAD(P)H dehydrogenase [quinone] 1 \\
\hline
\end{tabular}

\section{References.}

1. Bocci V. Is it true that ozone is always toxic? The end of a dogma. Toxicol Appl Pharmacol. 2006 Nov;216(3):493-504.

2. Jacobs MT Untersusuchung uber zwischenfalle und typische komplikationen in der Ozone Sauerstoff therapie. Ozonachrichten. 1982;5:1-5.

3. Andreula CF, Simonetti L, De Santis F, Agati R, Ricci R, Leonardi M. Minimally invasive oxygen-ozone therapy for lumbar disk herniation. AJNR. 2003 May;24(5):996-1000.

4. Paoloni M, Di Sante L, Cacchio A, Apuzzo D, Marotta S, Razzano M, Franzini M, Santilli V. Intramuscular oxygen-ozone therapy in the treatment of acute back pain with lumbar disc herniation: a multicenter, randomized, double-blind, clinical trial of active and simulated lumbar paravertebral injection. Spine. 2009;34(13):13371344.

5. Dahnhardt JE, Gygax M, Martignoni B, Suter P, Lussi A. Treating sensitive cervical areas with ozone. A prospective controlled clinical trial. Am J Dent. 2008;21(2):746.

6. Re L, Martínez-Sánchez G, Malcangi G, Mercanti A, Labate V. Ozone Therapy: A Clinical Study on the Pain Management. Int J Ozone Therap. 2008;7(1):37-44.

7. Chang JD, Lu HS, Chang YF, Wang D. Ameliorative effect of ozone on cytokine production in mice injected with human rheumatoid arthritis synovial fibroblast cells. Rheumatol Int. 2005 Dec;26(2):142-51.

8. Zamora ZB, Borrego A, Lopez OY, Delgado R, González R, Menéndez S, Hernández F, Schulz S. Effects of ozone oxidative preconditioning on TNF-alpha release and antioxidant-prooxidant intracellular balance in mice during endotoxic shock. Mediators Inflamm. 2005 Feb 24;2005(1);24:16-22.

9. Fuccio C, Luongo C, Capodanno P, Giordano C, Scafuro MA, Siniscalco D, Lettieri $B$, Rossi F, Maione S, Berrino L. A single subcutaneous injection of ozone prevents allodynia and decreases the over-expression of pro-inflammatory caspases in the orbito-frontal cortex of neuropathic mice. Eur J Pharmacol. 2009;603:42-49.

10. Ajamieh HH, Menendez S, Martinez-Sanchez G, Candelario JE, Re L, Giuliani A, Leon Fernandez OS. Effects of ozone oxidative preconditioning on nitric oxide generation and cellular redox balance in a rat model of hepatic ischaemiareperfusion. Liver Int. 2004;24(1):55-62.

11. Martinez-Sanchez G, Al-Dalain SM, Menendez S, Re L, Giuliani A, CandelarioJalil E, Álvarez H, Fernández-Montequín Jl, León OS. Therapeutic efficacy of ozone in patients with diabetic foot. Eur J Pharmacol. 2005 Oct;523(1-3):151-161. 12. Bocci V, Borrelli E, Travagli V, Zanardi I. The ozone paradox: ozone is a strong 
oxidant as well as a medical drug. Med Res Rev. 2009 Jul;29(4):646-682.

13. Wentworth P Jr, McDunn JE, Wentworth AD, Takeuchi C, Nieva J, Jones T, Bautista C, Ruedi JM, Gutierrez A, Janda KD, Babior BM, Eschenmoser A, Lerner RA. Evidence for antibody-catalyzed ozone formation in bacterial killing and inflammation. Science 2002;298:2195-2199.

14. Burke JG, Watson RW, McCormack D, Dowling FE, Walsh MG, Fitzpatrick JM. Intervertebral discs which cause low back pain secrete high levels of proinflammatory mediators. J Bone Joint Surg Br. 2002 Mar;84(2):196-201.

15. Miyamoto H, Saura S, T TH. The role of cyclooxygenase-2 and inflammatory cytokines in pain induction of herniated lumbar intervertebral disc. Kobe $\mathrm{J}$ Med Sci. 2000 Apr;46(1-2):13-28.

16. Re L, La terapia con ossigeno-ozono o ozormesi: recenti acquisizioni scientifiche. Medici \& Medici. 2008;16:18-20.

17. Watson J. Type 2 diabetes as a redox disease. Lancet. 2014;383(9919):841843. doi:10.1016/S0140-6736(13)62365-X.

18. Mason HS, North JC, Vanneste M. Microsomal mixed-function oxidations: the metabolism of xenobiotics. Fed Proc. 1965 Sep-Oct;24(5):1172-1180.

19. Simmons SO, Chun-Yang Fan, and Ramabhadran R. Cellular stress response pathway system as a sentinel ensemble in toxicological screening. Toxicol Sci. 2009 Oct;111(2):202-225.

20. Pecorelli A, Bocci V, Acquaviva A, Belmonte G, Gardi C, Virgili F, Ciccoli L, Valacchi G. NRF2 activation is involved in ozonated human serum upregulation of HO-1 in endothelial cells. Toxicol Appl Pharmacol. 2013 Feb;267(1): 30-40.

21. Re L, Martínez-Sánchez G, Bordicchia M, Malcangi G, Pocognoli A, MoralesSegura MA, Rothchild J, Rojas A. Is ozone pre-conditioning effect linked to Nrf2/ EpRE activation pathway in vivo? A preliminary result. Eur J Pharmacol. 2014 Nov 5;742:158-162.

22. Laroche ML, Charmes JP, Nouaille Y, Picard N, Merle L. Is inappropriate medication use a major cause of adverse drug reactions in the elderly? $\mathrm{Br} \mathrm{J}$ Clin Pharmacol. 2007 Feb;63(2):177-186.

23. Re L, Malcangi G, Martinez-Sanchez G. Medical ozone is now ready for a scientific challenge: current status and future perspectives. J Exp Integr Med. 2012;2(3):193-196. 